\title{
HOW UNIFORM IS SPECIES DIVERSITY IN TROPICAL FORESTS?
}

\author{
Pavel Kindlmann ${ }^{1} \&$ Carlos A. Vergara Cassas $^{2}$ \\ ${ }^{1}$ Biodiversity Research Centre, Institute of Systems Biology and Ecology AS CR, Na Sádkách 7, \\ CZ-370 05 České Budějovice, and Institute for Environmental Studies, Faculty of Science, Charles \\ University, Benátská 2, CZ-128 01 Prague 2, Czech Republic \\ ${ }^{2}$ Universidad Católica Boliviana, Unidad Académica Campesina de Carmen Pampa, \\ Coroico - Nor Yungas, La Paz, Bolivia
}

\begin{abstract}
Questions concerning species diversity have attracted ecologists for over a century. One of these factors is the sampling effort - the "botanist effect," which can be, for example, the number of orchidologists in the region. The sampling effort can also account for the fact that most endemic orchid species are found close to roads, which indicates that orchid diversity may decline from the forest edge towards its interior. Here we tested this hypothesis, using data on orchid species from Bolivia. We found opposite trends in terrestrial and epiphytic species. Both species diversity and number of individuals of terrestrial species declined toward the forest interior. However, for epiphytic species, both species diversity and number of individuals of species increased toward the forest interior. Only because of the prevalence of the terrestrial species did the total number of species and the total number of individuals decline towards the forest interior. Thus, when making conclusions about the trends in orchid diversity towards the interior of the forest, their life mode should be taken into account. The reasons for the trends observed are quite straightforward. Toward the forest interior, density of the trees increases, and therefore the amount of light available on the ground declines. Hence, habitats close to the openings (roads, meadows, fields, etc.) are more suitable for terrestrial species, whereas those deep in the forest interior are more suitable for epiphytic species because of the availability of host trees.
\end{abstract}

RESUMEN. Las preguntas acerca de la diversidad de especies ha atraído a los ecologistas desde hace más de un siglo. Uno de los factores que genera preguntas es la distribución de las especies, misma que se podría ser un resultado del llamado "efecto de los botánicos" o efecto del esfuerzo de colección, así por ejemplo una zona donde existan muchos orquideólogos, con seguridad tiene una gran diversidad, pero al mismo tiempo gran esfuerzo de colección. Otro fenómeno común asociado al esfuerzo de colección de encuentra en la distribución de especies endémicas, que aparecen como más diversas al borde de los carreteros, y que declinan su diversidad hacia el interior del bosque. En este estudio probamos esta hipótesis utilizando datos de especies de orquídeas bolivianas. Se encontró diferencias entre especies terrestres y epífitas. En el caso de las terrestres, tanto la diversidad como el número de individuos disminuyó hacia el interior del bosque. Sin embargo, las especies epífitas incrementaron su abundancia y diversidad hacia el interior del bosque. Las razones que explican los patrones observados son evidentes, ya que hacia el interior del bosque hay mayor densidad de árboles por lo tanto hay menor cantidad de luz que llega al suelo, por lo cual la diversidad de las especies terrestres declina. Así, los hábitats cercanos a claros de bosque son más propicios para especies terrestres, mientras que los que se encuentran al interior del bosque son apropiados par alas especies epífitas debido a una mayor disponibilidad de árboles hospederos.

KEY WORDS: Orchidaceae, species diversity, sampling effort, tropical forest, Bolivia

Questions concerning species diversity have attracted ecologists for over a century (Sch.delbauerov. et al., 2009). Increase in species richness from the poles to the tropics (Pianka, 1966; Rohde, 1992; Willig et al., 2003; Hillebrand, 2004) and with area (Arrhenius, 1921; Gleason, 1922; Williamson, 1988; Rosenzweig,
1995) is still one of the main topics in contemporary ecology. More recently, the amount of energy available (i.e., that which can be converted into biomass) for net primary productivity has been revealed to be an important determinant of species richness (Wright, 1983; Wylie \& Curie, 1993a,b; Pelkey et al., 2000; 


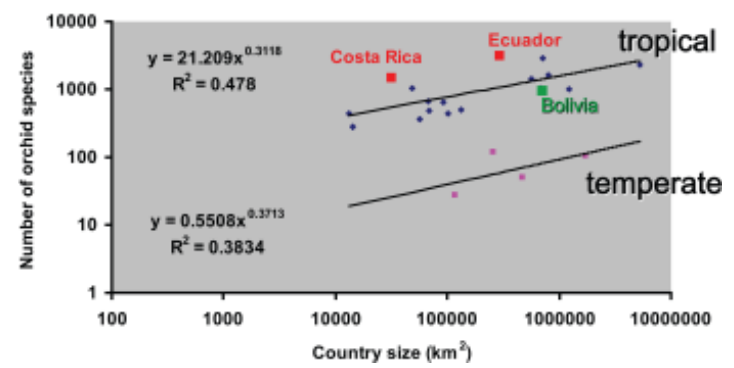

FIgURE 1. Numbers of orchid species in various countries of the whole of Latin America plotted against size of each country. Different dependences hold for tropical and temperate countries: the fitted lines are almost equally steep, but that for the tropical countries lies far above that for temperate ones. The $\mathrm{R}^{2}$ values are coefficients of determination, denoting the proportion of variability in the data explained by the fitted line $(53 \%$ and $25 \%$, respectively, in our case).

Evans et al., 2005; Storch et al., 2005). Area is clearly the most influential determinant, but other factors may also be important.

One of these factors is the sampling effort - the "botanist effect" - which is related to, for example, the number of orchidologists in the region. The "botanist effect" is thought to be the reason for higher plant species richness in areas where botanists are disproportionately present as an artefactual consequence of a more thorough sampling (Pautasso \& McKinney, 2007). For orchids this is illustrated in Figure 1 using the examples of Ecuador, Costa Rica, and Bolivia, which are similar to each other in many respects: they are tropical, mountainous countries with similar diversity of habitats and similar climatic conditions. Ecuador and Costa Rica were well studied and are above the regression line. There is much less known about orchid species in Bolivia, which is below the line.

The sampling effort can also cause the effect observed by Endara et al. (2007) - most endemic orchid species were found close to the roads. Thus it seems that orchid diversity declines from the forest edge towards its interior. Here we test this hypothesis, using data on orchid species from Bolivia.

\section{Description of study area}

Our study area covered approximately 80 hectares of the Uchumachi mountain close to the settlement of Carmen Pampa (16 $20^{\prime} 30^{\prime}$ ' S, 67 $50^{\circ} 00^{\prime \prime}$ W) in the

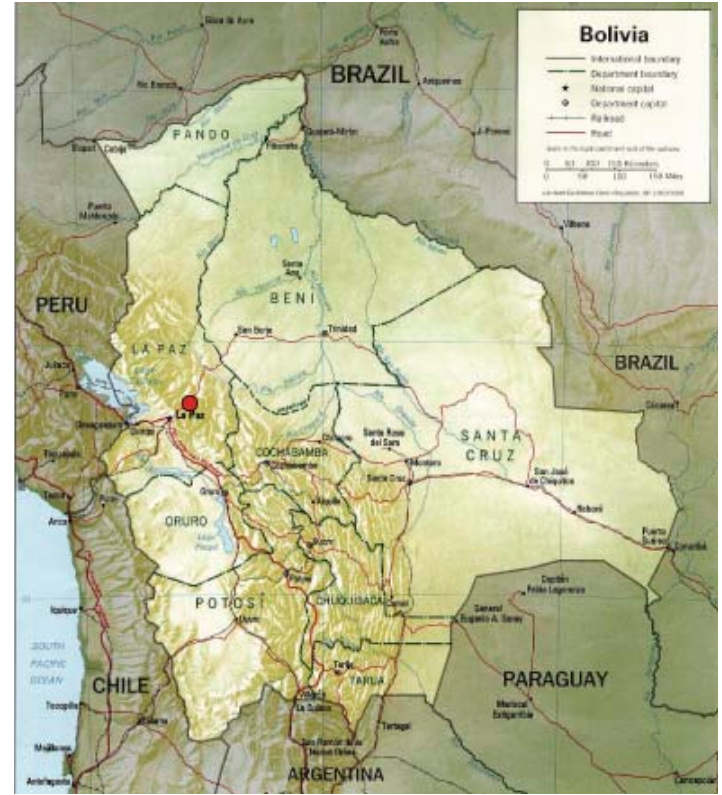

FIgURE 2. The approximate position of the study area is indicated here by the red dot.

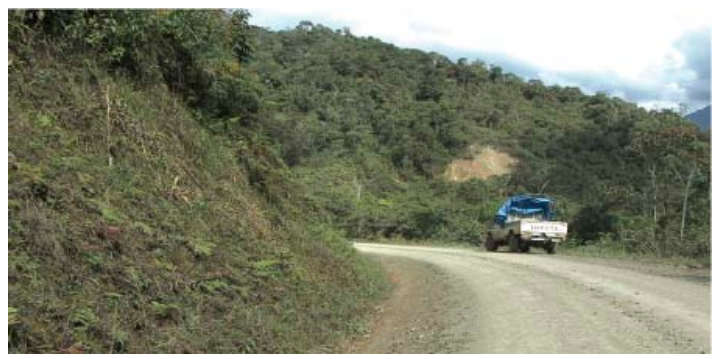

Figure 3. The the study area.

municipality of Coroico, province of Nor Yungas, department of La Paz, Bolivia, in the eastern slopes of the Andes.

The elevation of our plots ranged from 1957 to 1995 meters above sea level. The eco-region here, called yungas, is characterized by mountain chains with wide slopes and long valleys formed from sedimentary and metamorphic rock (Fig. 2). Elevations range from 400 to 2800 meters above sea level (Morales, 2004). The study area consisted of the road verge, secondary forest, and primary forest. The secondary forest hosts a great diversity of species, including tree ferns (Cyathea amazónica Domin), "sikilis" (Inga sp.), walnut (Juglans boliviana Dode), "ambaibos" (Cecropia angustifolia Tr.cul), and a diversity of ferns, mosses, and palms. It is characterized by a 


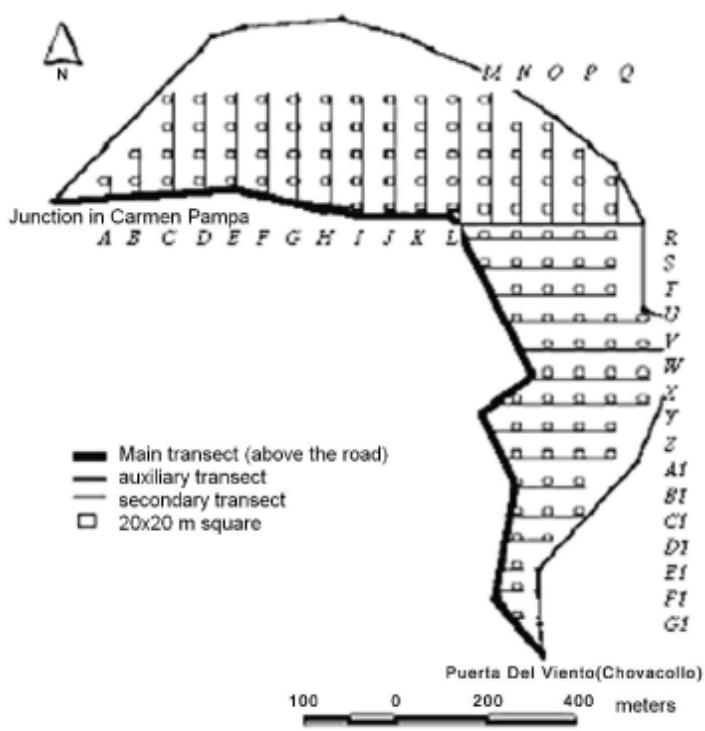

FIgURE 4. Plan of the study area. The thick black line is the road. Thin lines indicate the transects, and small circles are the plots.

dense understory with evidence of selective logging. The primary forest is characterized by the presence of taller trees, wider in diameter, and a reduced understory due to a reduction of light in the forest floor. Human activity is also much reduced here. This forest is dominated by tree ferns (Cyathea amazónica), individuals from Lauraceae, "espeke" (Clusia haughtii Cuatrec), "leche leche" (Sapium aereum Klotzsch ex Müll.Arg.), and "mata palo" (Ficus obtusifolia Roxb.) that can reach diameters of over $100 \mathrm{~cm}$ and account for a large part of the basal area. Other species such as "jaluti" (Miconia guianensis Cogn.), wild papaya (Oreopanax sp.), and "suti suti" (Miconia minutiflora DC.) are found at densities of one or less per hectare, which indicates that they may be under the threat of extinction (Endara, 2001).

The average of ten years of meteorological data from an on-site weather station shows that the average temperatures in the warmest month (January) are above $19 \mathrm{C}$ and in the coldest months (June and July) about $15 \mathrm{C}$, with maximum yearly temperatures around $25 \mathrm{C}$ and minimum yearly temperatures of 15 C. The total annual precipitation is $2390 \mathrm{~mm}$, with maximum precipitation from December to April (200$300 \mathrm{~mm}$ per month) and no month with less than 80 $\mathrm{mm}$. Relative humidity is between $50-100 \%$.
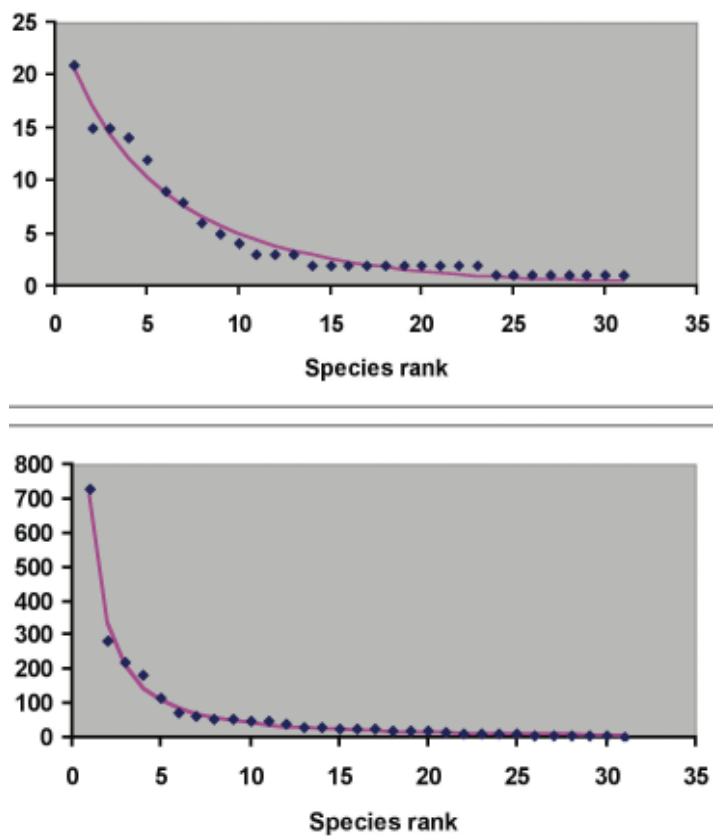

Figure 5. Number of squares in which the species was found (top) and number of individuals of the species (bottom) against the species rank, when the species are ranked from the commonest to the rarest.

\section{Methods}

We used linear transects perpendicular to the road depicted in Figure 3. Along the transects, we set up 117 evenly spaced $20 \times 20 \mathrm{~m}$ plots, in which all orchid species were determined. The accuracy of species identification was verified using the orchid collection in the Herbario Nacional de Bolivia. Out of the 117 plots, 33 were adjacent to the road (habitat R), 40 were in the secondary forest (habitat $\mathrm{S}$ ), and 44 were in the primary forest (habitat P; see Fig. 4).

\section{Results}

Altogether, 2159 individuals were found in the 117 plots. The orchids showed the classical negative exponential pattern, when the species were ranked from the commonest to the rarest (Fig. 5). Table 1 shows the parameter values $(\mathrm{a}, \mathrm{b}, \mathrm{c})$ and residual sums of squares (RSS) of the function $y=a \cdot e^{-b x c}$, fitted to the relationship between the number of squares in which the species was found and species rank, when the species are ranked from the commonest to the rarest ("Squares") and those of the function $y=a \cdot e^{-b x c}$, fitted to the relationship between the 
TABLA 1. Parameter values $(a, b, c)$ and residual sums of squares (RSS) of the function $\mathrm{y}=a \cdot e^{-b x c}$, fitted to the relationship between the number of squares in which the species was found and species rank, when the species are ranked from the commonest to the rarest ("Squares") and those of the function $y=a \cdot e^{-b x c}$, fitted to the relationship between the number of individuals of the species and species rank, when the species are ranked from the commonest to the rarest ("Individuals").

\begin{tabular}{l|r|r} 
& Individuals & Squares \\
\hline $\mathrm{a}$ & 286625 & 26.55 \\
\hline $\mathrm{b}$ & 6.00 & 0.25 \\
\hline $\mathrm{c}$ & 0.17 & 0.83 \\
\hline RSS & 5288.1 & 21.8
\end{tabular}

number of individuals of the species and species rank, when the species are ranked from the commonest to the rarest ("Individuals"). Table 2 shows the species found in individual habitats. Out of the total of 31 species (13 epiphytic and 18 terrestrial species), only one species occurred in all three habitats, the epiphytic Pleurothallis xanthochlora Rchb.f. There were 3 epiphytic and 6 terrestrial species, which occurred in two habitats. The remaining 9 epiphytic and 12 terrestrial species were specialized to only one of the habitats.

Figure 6 shows the average number of species per square and average number of individuals per square that were found at the edge of the road, in the secondary forest, and in the primary forest for terrestrial and epiphytic species. Clearly, both the number of terrestrial species and the number of individuals of terrestrial species strongly decreased toward the interior of the forest. The largest number of individuals and species was in the road verge, followed by the secondary forest, and finally the primary forest with the smallest number of terrestrial species and individuals. An opposite situation occurred in epiphytic species. Both the number of epiphytic species and the number of individuals of epiphytic species strongly increased toward the interior of the forest. The smallest number of individuals and species was in the road verge, followed by the secondary forest, and the primary forest with the largest number of epiphytic species and individuals.

\section{Discussion and conclusions}

We found opposite trends in terrestrial and epiphytic species. Both species diversity and number of individuals of terrestrial species declined toward

TABLA 2. Alphabetical list of epiphytic and terrestrial species found in individual habitats ( $\mathrm{R}$ - road verge, $\mathrm{S}-$ secondary forest, $\mathrm{P}$ - primary forest). Species common to all three habitats is in red and highlighted in yellow; species common to two habitats are highlighted in blue.

\begin{tabular}{|c|c|c|c|c|c|c|c|}
\hline Epiphytes & $\mathbf{R}$ & $\mathbf{S}$ & $\mathbf{P}$ & Terrestrials & $\mathbf{R}$ & $\mathbf{S}$ & $\mathbf{P}$ \\
\hline \multicolumn{8}{|l|}{ Acianthera heliconioides (Luer \& R.Vásquez) } \\
\hline Pridgeon \& M.W.Chase & 0 & 0 & 4 & Bletia catemulate Ruiz \& Pav. & 38 & 0 & 0 \\
\hline Cyrtochilum myanthum (Lindl.) Kraenzl. & 0 & 0 & 8 & Elleanthus hookerianus (Barb.Rodr.) Garay & 3 & 0 & 0 \\
\hline Epidendrum jajense Rchb.f. & 8 & 0 & 5 & Epidendrum funckianum A.Rich. \& Galeotti & 691 & 37 & 0 \\
\hline Epidendrum macrocarpum Rich. & 0 & 2 & 7 & Epidendrum secundum Jacq. & 27 & 0 & 0 \\
\hline Epidendrum tridens Poepp. \& Endl. & 2 & 0 & 0 & Stelis sp. 2 & 26 & 47 & 0 \\
\hline Notylia peruviana (Schltr.) C.Schweinf. & 9 & 0 & 0 & Habenaria macronectar (Vell.) Hoehne & 26 & 0 & 0 \\
\hline Oncidium tigratum Rchb.f. \& Warsz. & 0 & 0 & 17 & Koellensteinia boliviensis (Rolfe ex Rusby) Schltr. & 9 & 0 & 0 \\
\hline Pleurothallis cordata (Ruiz \& Pav.) Lindl. & 0 & 0 & 5 & Maxillaria aggregate (Kunth) Lindl. & 6 & 0 & 0 \\
\hline Pleurothallis linguifera Lindl. & 0 & 21 & 0 & Maxillaria longicaulis Schltr. & 3 & 0 & 0 \\
\hline Pleurothallis xanthochlora Rehb.f. & 46 & 76 & 60 & Ornithidium aureum Poepp. \& Endl. & 52 & 0 & 0 \\
\hline Restrepia antennifera Kunth & 0 & 0 & 114 & Polystachya boliviensis Schltr. & 28 & 0 & 0 \\
\hline Scelochilus larae Dodson \& R.Vásquez & 0 & 0 & 24 & Sobralia bletiae Rchb.f. & 16 & 3 & 0 \\
\hline \multirow[t]{6}{*}{ Stelis sp. 1} & 0 & 33 & 16 & Sobralia dichotoma Ruiz \& Pav. & 46 & 0 & 0 \\
\hline & & & & Sobralia dorbignyana Rchb.f. & 24 & 0 & 0 \\
\hline & & & & Sobralia fimbriata Poepp. \& Endl. & 148 & 73 & 0 \\
\hline & & & & Sobralia sp. & 0 & 37 & 17 \\
\hline & & & & Sobralia yauaperyensis Barb.Rodr. & 258 & 0 & 26 \\
\hline & & & & Zygopetalum maculatum (Kunth) Garay & 61 & 0 & 0 \\
\hline
\end{tabular}


Average No. of species per square

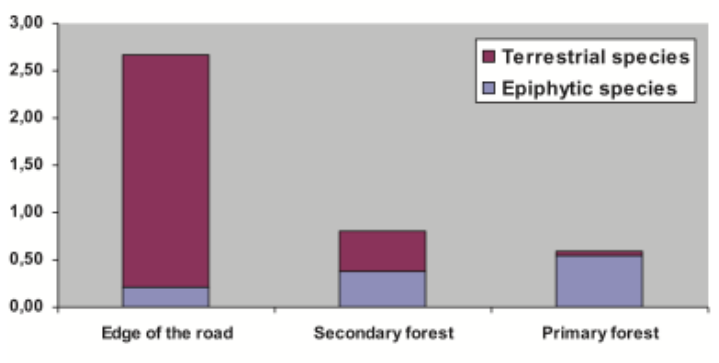

Average No. of individuals per square

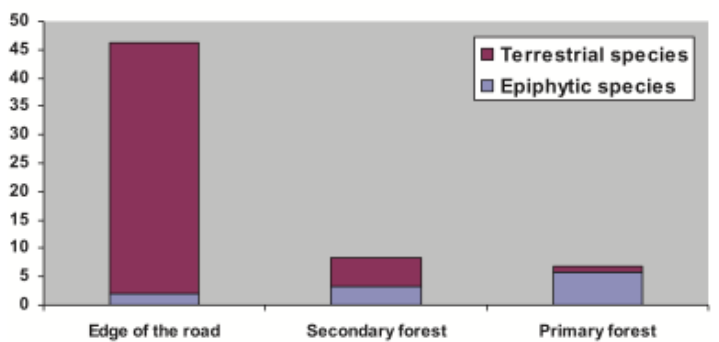

FIGURE 6. Average number of species per square (top) and average number of individuals per square (bottom) that were found at the edge of the road, in the secondary forest, and in the primary forest for terrestrial and epiphytic species.

the forest interior. However, in epiphytic species both species diversity and number of individuals of epiphytic species increased toward the forest interior. Only because of the prevalence of the terrestrial species did the total number of species and the total number of individuals decline toward the forest interior. Thus, when making conclusions about the trends in orchid diversity toward the interior of the forest, their life mode should be taken into account. The reasons for the trends observed are straightforward. Toward the forest interior, density of the trees increases, and therefore the amount of light available on the ground declines. Therefore, habitats close to the openings (roads, meadows, fields, etc.) are more suitable for terrestrial species, whereas those deep in forest interior are more suitable for epiphytic species due to the availability of host trees.

AcKNOwLEDGMENTS. The research was supported by the grant No. LC06073 of the Czech Ministry of Education.

\section{LITERATURE CITED}

Arrhenius, O. 1921. Species and area. J. Ecol. 9: 95-99.

Endara, A. R. 2001. Inventario de las especies forestales del bosque húmedo tropical premontano del Cerro Uchumachi sector Carmen Pampa. Tesis De Grado. Universidad Católica Boliviana - Unidad Académica Campesina de Carmen Pampa. La Paz, Bolivia.

Endara, L., N. H. Williams \& S. León-Yánez, S., 2007. Patrones de endemismo de orquídeas endémicas Ecuatorianas: perspectivas y prioridades para la conservación. Pp. 63-70 in: A. M. Pridgeon \& J. P. Suárez (eds.). Proceedings of the second scientific conference on Andean orchids. Universidad Técnica Particular de Loja, Loja, Ecuador.

Evans, K. L., J. J. D. Greenwood \& K. J. Gaston. 2005. The roles of extinction and colonization in generating species-energy relationships. J. Anim. Ecol. 74: 498507.

Gleason, H. A. 1922. On the relation between species and area. Ecology 3: 158-162.

Hillebrand, H. 2004. On the generality of the latitudinal diversity gradient. Amer. Natur. 163: 192-211.

Morales, C. B. 2004. Manual de ecología. 2. ediciíon. Editorial Instituto de Ecología, Universidad Mayor de San Andrés. La Paz, Bolivia.

Pautasso, M. \& M. L. McKinney. 2007. The botanist effect revisited: plant species richness, county area, and human population size in the United States. Conserv. Biol. 21: 1333-1340.

Pelkey, N. W., C. J. Stoner \& T. M. Caro. 2000. Vegetation in Tanzania: assessing long term trends and effects of protection using satellite imagery. Biol. Conserv. 94: 297-309.

Pianka, E. R. 1966. Latitudinal gradients in species diversity: a review of concepts. Amer. Natur. 100: 33-46.

Rohde, K. 1992. Latitudinal gradients in species diversity: the search for the primary cause. Oikos 65: 514-527.

Rosenzweig, M. L. \& E. A. Sandlin. 1997. Species diversity and latitudes: listening to area's signal. Oikos 80: 172176.

Schödelbauerová, I., D. L. Roberts \& P. Kindlmann. 2009. Size of the protected areas is the main determinant of species diversity in orchids. Biol. Conserv. 142: 23292334.

Storch, D., K. L. Evans \& K. J. Gaston. 2005. The speciesarea-energy relationship. Ecol. Letters 8: 487-492.

Villca, H. R. 2001. Evaluación de la erosión hidrica en un sistema agroforestal café (Coffea arabica) con sikili (Inga adenophylla) bajo dos métodos de control de maleza con chonta y machete en Carmen Pampa. Tesis de grado. Universidad Católica Boliviana - Unidad Académica Campesina de Carmen Pampa. La Paz, Bolivia. 
Williamson, M. H. 1988. Relationship of species number to area, distance and other variables. Pp. 91-115 in: A. A. Myers and P. S. Giller (eds.). Analytical biogeography. Chapman and Hall, London, UK.

Willig, M. R., D. M. Kaufman \& R. D. and Stevens. 2003. Latitudinal gradients in biodiversity: pattern, process, scale, and synthesis. Ann. Rev. Ecol. Syst. 34: 273-309.

Wright, D. H. 1983. Species-energy theory: an extension of species-area theory. Oikos 41: 496-506.
Wylie, J. L. and Currie, D. J. 1993a. Species-energy theory and patterns of species richness: I. Patterns of bird, angiosperm, and mammal species richness on islands. Biol. Conserv. 63: 137-144.

Wylie, J. L. \& D. J. Currie. 1993b. Species-energy theory and patterns of species richness: II. Predicting mammal species richness on isolated nature reserves. Biol. Conserv. 63: 145-148. 